\title{
STATE POLITICAL AND ECONOMIC CAPACITIES AND THE QUALITY OF GOVERNMENT IN ASIAN COUNTRIES ${ }^{1}$
}

\author{
S.-H. Park, The Catholic University of Korea ${ }^{2}$ (Corresponding Author ${ }^{3}$ ) \\ M. Wilding, The University of Salford
}

\begin{abstract}
This study analyzed the impacts of state political and economic capacities on the quality of government in 40 Asian countries. Quality of government data for 2002 and 2010 were obtained from four elements of the World Bank Governance Index, and the same or closest year's data for political and economic capacity were collected from other well-known indices. The analysis reveals that economic growth influences four elements in both developed and developing countries, although the effects of economic freedom differ between these two groups of states. While political capacity (i.e., civil empowerment, democracy, and press freedom) is found to have an effect on all four of the governance elements in developed countries, it influences just two elements in developing economies. Thus, the results suggest that the quality of government in Asia is not only improved by economic capacity but might also be enhanced by consolidation of democracy, particularly once a certain degree of economic development is achieved.
\end{abstract}

Keywords: quality of government, state capacity, political capacity, economic capacity, governance in Asia

\footnotetext{
${ }^{1}$ Draft version, post review. Please note that a number of minor changes were made prior to publication. The latest version, published in Asian Journal of Political Science can be obtained from https://doi.org/10.1080/02185377.2014.961024

${ }^{2}$ Funding: This work was funded by the 2013 Research Fund of the Catholic University of Korea.

${ }^{3}$ Contact: nice113@catholic.ac.kr
} 


\section{STATE POLITICAL AND ECONOMIC CAPACITIES AND THE QUALITY OF GOVERNMENT IN ASIAN COUNTRIES}

\section{INTRODUCTION}

Following the expansion of economic capacity in Asian countries from the latter part of the 20th century, along with demands for democracy, concerns about quality of government have emerged. Some Asian economies, including Japan, South Korea, Taiwan, and Turkey experienced miraculous growth before undergoing regime change from the mid-1990s. More recently, a number of Southeast Asian countries, including Indonesia, Malaysia, and Thailand, have embarked on massive programs of economic development, and have also experienced political changes over the last decade. The Chinese and Indian economies are developing remarkably, and this is also the case for Qatar and the United Arab Emirates in the Middle East, while the economies of Kazakhstan and Uzbekistan in Central Asia are newly developing. The Arab Spring which began in Tunisia in late 2010 has spread through the Middle East. However, there has been little research on the impact of these changing state political and economic capacities, including civil empowerment, democracy, press freedoms, national wealth, economic freedom, and trade openness upon quality of government in Asia, in the sense of whether government is more or less stable, transparent, able to provide effective public services and policies, and enforce the rule of law. This represents a significant oversight when considering the extent of changes that have taken place. The present study aims to address this gap in the literature.

Quality of government is increasingly seen as central to the provision of public goods, rule of law, regulation, and accountability. Since the early work of La Porta et al. (1999), a number of researchers have attempted to conceptualize and measure the construct, and to reveal its determinants (e.g., Knack, 2001; Treisman, 2002; Adserà et al., 2003; Hanousek and Palda, 2004; Fogel, 2006). Rothstein and Teorell (2008) made the case that this extant literature has ranged from the very broad on the one hand to the narrow and exclusive on the other. However, their approach, which focused on impartiality of government institutions, did not explicitly address political stability or corruption. The lack of attention given to political stability is also an issue in other studies which have attempted to define the concept (Knack, 2001; Treisman, 2002). The present study thus includes corruption control and political stability when measuring quality of government, and draws on the World Bank's research on good governance in order to take a statistical approach which utilizes government indicators. Despite the pitfalls of using 
data from international organizations (Pollitt, 2011), a statistical approach has the advantage of allowing the effect of state political and economic capacity on quality of government to be measured.

Thus this study compares the quality of government of Asian countries based on four measures (corruption control, government effectiveness, political stability, and rule of law), and examines state political and economic capacities, before analyzing the impact of these capacities on quality of government. In total, 40 countries are examined from across the Asian continent, a full list of which is included in Appendix 1. Data from 2002 or the closest available year were obtained for the dependent variables from the Quality of Government Institute at the University of Gothenburg (Teorell et al., 2012a), while data for 2012 or the closest available year were obtained for all variables from a range of sources: Freedom House, CIRI (CingranelliRichards) Human Rights Dataset, Heritage Foundation, World Bank, and International Monetary Fund (IMF).

\section{THEORETICAL APPROACH AND MODEL SPECIFICATION}

In order to explore whether increased state political and economic capacities can raise quality of government, this section defines key concepts, reviews the literature on the relation between state political and economic capacities and quality of government, and describes the models and data collection methods. First of all, it is important to clarify the terms state and government. The state is a complex phenomenon which is notoriously difficult to define, not least because the term is used in the definition of other central concepts in the study of politics (Jessop, 2007). While acknowledging the problematic nature of achieving such a definition, a popular approach has involved emphasizing the state's institutional features, i.e., territory, population, and apparatus (Oppenheimer, 1908; Schmitt, 1928). Thus, the state has a government, but is more than just its government. Indeed, approaches to the state which emphasize mechanisms of power (Weber, 1948) also require taking a wider perspective than that of government, which has been described as the major agent of the state with responsibility for carrying out the day-to-day business of the state (Laski, 1935).

\section{Quality of Government}

Quality of government has been defined in various ways, ranging from narrow to broad. At the narrower end of the spectrum, La Porta et al. (1999: 223) define the term as the extent to which government is 'good for economic development'. Other researchers have used the term 
to refer to the degree to which the executive branch of government is accountable, effective, empowering, transparent, and stable (Rothstein, 2003). Focusing on the executive branch has the limitation that it ignores wider government institutions such as the legislative and judicial branches. On the other hand, broader approaches may refer to the state more generally, and thus include state capacities. For example, Bueno de Mesquita et al. (2003) are interested in the degree to which a state is democratic, invulnerable, affluent, inclusive, and legitimate. Rothstein and Teorell (2008: 165) found the middle ground between the narrow and broad with their definition of the term as 'the impartiality of institutions that exercise government authority' and focus on three aspects: democracy, rule of law, and efficiency/effectiveness. However, their definition did not recognize political stability, nor was checking corruption explicitly identified. Similarly, political stability was not recognized in the work of Knack (2001), which evaluated quality of government in terms of corruption, bureaucratic quality, and rule of law, nor that of Treisman (2002) which assessed it based on perceived corruption and the effectiveness of public good provision in health care, education, and infrastructure.

As can be seen from the above discussion, it is important to achieve a balance between the broad and narrow, and to include political stability and corruption control, but to also make a distinction between quality of government and state economic and political capacities (i.e., the tools which government uses to improve). We therefore define quality of government as the extent to which government provides effective public services and policies, is politically stable and free from corruption, and able to enforce the rule of law. This is a definition which focuses on the products or outcomes of government. Although government has some control over its political and economic capacities, to some extent these are the inputs which government can work with. More specifically, we suggest that a number of World Bank Governance Indicators (WBGI) can be used to measure the quality of government. Though governance has been taken to mean everything and anything (Rhodes, 2000), including market based approaches to government (Kettl, 1993), the move to the hollow state (Milward and Provan, 2000), and the reinvention of government through new public management (Osborne and Gaebler, 1992), the World Bank uses the term as follows: 'Governance consists of the traditions and institutions by which authority in a country is exercised' (World Bank, n.d.).

The World Bank's interest in good governance is not new. The concept was first used by the former president Barber Conable to refer to a 'public service that is efficient, a judicial system that is reliable, and an administration that is accountable to its public' (World bank, 1989: xii). Although initially reluctant to use the good adjective (Frischtak, 1994), the organization's use of the term increased in the context of the focus on government performance 
in the development process. In particular, four of the World Bank's governance values, usually associated with good governance can be used to enrich our definition of quality of government ${ }^{4}$. Corruption control reflects the extent to which public power is controlled not to be exercised for private gains. Government effectiveness refers to the quality of public services, the expertise of the civil service and its independence from political pressure, the competence of policy decision making and implementation, and the credibility of government commitment to policies. Political stability means the improbability that the government will be overthrown or delegitimized by unconstitutional means. Rule of law is the extent to which agents have confidence in and abide by the rules of society, particularly in terms of contract enforcement, property rights, and crime and violence.

\section{State Capacity}

It is important to clarify what is meant by state capacity, particularly as the term has been used interchangeably with quality of government by some researchers (Charron and Lapuente, 2009). We use state capacity to describe the extent to which states have the ability to pursue their autonomous interests (Rueschemeyer and Evans, 1985; Skocpol, 1985). State capacity can be seen to have multiple dimensions, such as institutional, technical, administrative, and political capacities (Grindle et al., 2010). Economic capacity can be added to this list, not least because finance is a key resource and any state without sufficient funds will struggle to achieve its aims. While state capacity clearly refers to a broad range of factors, this study will focus on political and economic capacities in order to test the relationship with quality of government which, as discussed above, includes a number of institutional, technical, and administrative aspects.

\section{Political Capacity}

Following Grindle et al., we use the term political capacity to refer to 'the ability of states to respond to societal demands, allow for channels to represent societal interests, and incorporate societal participation in decision making' (2010: 10). Political capacity is clearly multidimensional and is concerned with democracy in the form of civil liberties, political rights, press freedom, and citizen empowerment (c.f. Lijphart, 1999; Przeworski et al., 2000; Vanhanen, 2000, 2003; Hadenius and Teorell, 2005). Civil liberties include freedom of belief,

\footnotetext{
${ }^{4}$ Although the World Bank is also concerned with voice and accountability (i.e., participation, and freedom of expression and association) and regulatory quality (i.e., the ability of government to formulate sound policies and rational regulations that prompt private-sector development), these have been excluded from this study due to the ways in which they overlap with state political and economic capacities.
} 
expression, and association as well as personal autonomy; political rights are the extent to which people can participate freely in the political process, including by voting, competing for public office, affiliating with political institutions, and electing representatives who are accountable to them; press freedom can be assessed in terms of laws and regulations, political pressures and controls, economic influences, and repressive actions; citizen empowerment is a complex mix of freedom of speech, workers' rights, and political participation.

\section{Economic Capacity}

We use the term economic capacity to refer to the ability of the state to manage its economic performance and facilitate an environment which is conducive to the business and financial transactions of corporations and citizens. Though this capacity may be seen as an end in itself, it may also be viewed as an intermediate end which facilitates state efforts to reduce corruption or improve government effectiveness (La Porta et al., 1999). More specifically, both economic growth, usually measured in terms of gross domestic product per capita (GDPC), and trade openness (i.e., the volume of international trade assessed as a ratio of total trade to GDP) can be associated with economic capacity to improve government (Knack, 2001; Adsera et al., 2003; Holmberg et al., 2009; Charron and Lapuente, 2010). Economic liberty, assessed in terms of institutional arrangements and policies, size of government, legal structure of property rights, access to sound money, freedom of trade, regulation of credit, and labor and business (Gwartney and Lawson, 2006 cited in Teorell et al., 2012b: 32), may also be associated with economic capacity to improve government (Goel and Nelson, 2005), although its two-sided effects have been discussed (Chang, 1999, 2000; Henderson, 1999; Weiss, 2000).

\section{The Relationship between State Capacity and Quality of Government}

Quality of government, economic development and the transition to democracy have become key themes across a range of countries, and state autonomy is key to understanding the connection between these concepts. States have autonomy in the sense that they independently formulate goals which are not always identical to priorities of groups within society (Rueschemeyer and Evans, 1985; Skocpol, 1985). Whether or not states are able to achieve these goals depends upon their capacities: state political and economic capacities, as outlined above, can directly impact the ability of states to meet their goals, and thus the quality of government.

The literature on the developmental state in Asia has been particularly interested in the state's role in economic development. However, there have been debates about the nature of 
this involvement, and more specifically, the level of state autonomy displayed. While a degree of state capacity is required to manage the economy, the role of the market is subject to different levels of emphasis. There are researchers who claim that market conforming methods of state intervention predominate, with their extensive reliance on public corporations and public investment in the market (Johnson, 1999), while others point to the importance of market augmenting methods which involve more state control and intervention (Amsden, 1989). Others still have seen this as a shifting relationship in which the state role, though based on alliances and cooperation from the beginning, is gradually reduced as large businesses become more independent (Kim, 1997).

Although there is a neo-liberal literature which perceives state transformation as retreat (Dunleavy and Hood, 1994; Dunleavy and O’Leary, 1987; Osborne and McLaughlin, 2002), there are significant bodies of research which are concerned with the ways in which improved state capacity may promote sustained development, and which suggest that 'high stateness' may even be advantageous in a competitive global economy (Evans, 1997: 67-68). States with a high level of economic liberty still require the capacity to maintain their institutional arrangements and policies, and respond to changes in the regional and global economy. The effects of a lack of state capacity in this area can be extremely damaging. For example, the Asian financial crisis of the late 1990s has been associated both with a lack of state capacity to manage the economy and cronyism (Henderson, 1999; Stiglitz, 2003). It is important to note that it can be more difficult for developing countries to manage economic liberalization, however, due to the disadvantages which they may face in the market as their nascent industries grow (Chang, 2000; Wade, 2010).

Increased national wealth should improve the state's capacity to achieve its goals, as the formulation and implementation of policies, provision of services, and functioning of bureaucracies all benefit from the availability of economic resources (La Porta et al., 1999). However, there may be significant differences in the ways in which governments attempt to utilize their resources and the strategies which they use in order to achieve their goals. The comparative literature on economic development has highlighted the importance of state intervention in industrial policy and emphasized that rapid growth in East Asia should not be attributed to liberalized economies (Deyo, 1987; Amsden, 1989). Indeed, economic liberalization came later when it could be of more benefit to the state and its economic goals. This process varies depending on the context of the given country, including its place in the world economy and level of development, among other factors (Hamilton and Kim, 1993). We expect to find that higher levels of national economic performance in the form of GDPC and 
trade openness lead to better quality of government (Adsera et al., 2003; Holmberg et al., 2009), but that this relationship might not be so straightforward when it comes to economic liberty, where we expect developed countries to reap more benefits.

Turning to the state political capacity, in principle, higher levels of democracy should lead to improved quality of government, as democratic channels allow for information to be fed back to government about the wants and needs of the citizenry and thus government can begin to be more effective in meeting these. Optimists have argued that democracy spurs development as it aids the potential for increased government accountability and efficiency, and may help to create a more market-oriented environment (White, 1995). There is some empirical support for this position. For example, the findings of La Porta et al. (1999) reveal political conditions (measured by ethnic heterogeneity and the legal system) to have a positive effect on quality of government.

It is important to note that state capacity's relationship with quality of government is not straightforward. While Bäck and Hadenius (2008) found a link between high levels of democracy and 'administrative capacity', they also found countries with low levels of democracy to perform worse than authoritarian regimes as democracies could steer from below and authoritarian states from above, states with low levels of democracy could be caught between the two. Others have found the relationship to be indirect; the impact of democracy on quality of government was analyzed by Charron and Lapuente (2010), who found democracy to be important in creating demand for quality of government when citizens prioritize mid-tolong-term investments over short-term needs. They suggest that this is a function of economic development. Based on the findings of previous studies, we expect to find that political capacity influences quality of government positively in developed economies, but that the results are less clear in their lesser developed counterparts.

\section{Model Specification and Data Collection}

\section{Dependent Variables: Quality of Government}

This study measured quality of government based on four elements of the World Bank Governance Index (WBGI):

1. Corruption control (CCE) gauges perceptions of corruption, from the frequency of 'additional payments to get things done' to the effects of corruption on business and 'grand corruption' in the political arena or the tendency of elites to engage in state capture. 
2. Government effectiveness (GEE) includes public good provision, the competence and quality of the bureaucracy, the independence of the civil service from political pressures, and the credibility of government commitment to policies.

3. Political stability (PSE) assesses perceptions of the likelihood that the government in power will be destabilized by unconstitutional or violent means.

4. Rule of law (RLE) measures perceptions of the incidence of crime, the effectiveness and predictability of the judiciary, and the enforceability of contracts, as well as the extent to which a society forms fair and predictable rules such as property rights.

These elements incorporate several hundred variables, and scores are calculated using data from a wide range of organizations. They are normally distributed with a mean of 0 and a standard deviation of 1 in each year of measurement. This suggests that most of the scores lie between -2.5 and 2.5, with higher scores corresponding to better outcomes (Teorell et al., 2012b: 28-29).

\section{Independent Variables: State Capacity}

As discussed above, state capacity can be considered to have political and economic aspects. Political capacity was measured for this study based on the following indices:

- The Empowerment Index (EMPINX) of the CIRI (Cingranelli-Richards) Human Rights Dataset is an additive index based on seven rights: foreign movement, domestic movement, freedom of speech, workers' rights, freedom of assembly and association, electoral self-determination, and freedom of religion. Ranking ranges from 0 (least democratic) to 14 (most democratic). Until 2006 it used only five indicators: freedom of movement, freedom of speech, workers' rights, political participation, and freedom of religion, and ranking ranged from 0 to 10 (Cingranelli and Richards, 2011). To enable comparisons between the 2002 and 2012 datasets for this study, the scale of the new EMPINX was proportionately converted to a ten point scale.

- The Democracy Index (DI), from Freedom House, measures both civil liberties (freedom of expression and belief, associational and organizational rights, and personal autonomy without interference from the state) and political rights (the ability of people to vote freely in legitimate elections, compete for public office, join political organizations, and elect representatives). Countries whose average ratings for political rights and civil liberties fall between 1.0 and 2.5 are designated free, those with ratings between 3.0 and 5.0 partly free, and those with ratings between 5.5 and 7.0 not free. 
- The Press Freedom Index (PFI), published by Freedom House, ranges from 0 (most free) to 100 (least free), based on three components: laws and regulations, political pressures and controls, and economic influences.

Economic capacity was measured based on the following three indices, which measure economic liberty, trade openness, and economic growth respectively:

- The Economic Freedom Index (EFI), from the Heritage Foundation, uses 10 broad indicators: business freedom, trade freedom, fiscal freedom, freedom from government, monetary freedom, investment freedom, financial freedom, property rights, freedom from corruption, and labor freedom. Ranking ranges from 0 to 100, with a higher score representing more economic freedom.

- The Trade Openness indicator (OPENK) of the Penn World Table, published by the Center for International Comparisons at the University of Pennsylvania, is measured as a ratio of total trade (exports plus imports) to GDP in constant prices, with a reference year of 2005, where GDP for a given year is obtained by adding consumption, investment, government, and exports, and subtracting imports.

- GDP per capita (GDPC), from the World Bank's World Development Index, is adjusted by purchasing power parity, where GDP is converted to constant 2005 international dollars (an international dollar has the same purchasing power over GDP as a US dollar has in the United States) using purchasing power parity rates.

Due to the differences between developed and developing countries, the SPSS multiple pooled-regression results are presented not only at an aggregate level for all 40 countries, but are also divided according to developed and developing economies. A 2011 GDPC of $\$ 5,000$ was used as the cut-off point, which is equivalent to $33.68 \%$ of the mean GDPC for the 40 countries. This resulted in two categories of 20 countries $^{5}$.

\footnotetext{
${ }^{5}$ The developed countries were Bahrain, Brunei, China, Iran, Israel, Japan, Jordan, Kazakhstan, South Korea, Kuwait, Malaysia, Oman, Qatar, Saudi Arabia, Singapore, Taiwan, Thailand, Turkey, Turkmenistan, and the United Arab Emirates. The developing countries were Afghanistan, Bangladesh, Bhutan, Cambodia, India, Indonesia, Iraq, North Korea, Kyrgyzstan, Laos, Mongolia, Myanmar, Nepal, Pakistan, Philippines, Sri Lanka, Tajikistan, Uzbekistan, Vietnam, and Yemen.
} 


\section{CHANGES IN STATE CAPACITY AND QUALITY OF GOVERNMENT IN ASIAN COUNTRIES}

\section{Recent Political and Economic Changes}

As democracy is consolidated, the political capacity of countries seems to increase. With regard to Northeast Asia, a number of peaceful regime changes have taken place. Japan's Liberal Democratic Party, which had held power since 1955, lost its majority in the Diet in the August 1993 general election, when an eight-party coalition led by Hosokawa Morihiro formed the first non-Liberal Democratic Party government. The Liberal Democratic Party subsequently returned to power when Hashimoto Ryutaro was elected prime minister in 1996. However, a three-party coalition government, with the Democratic Party's Hatoyama Yukio as prime minister, took office after the 2009 election. In South Korea, once Kim Young-Sam was elected president in 1992, a democratic regime emerged along with increased political and civil rights after more than 30 years of authoritarian rule. Democracy was consolidated when the major opposition party leader, Kim Dae-Jung, and his successor, Roh Moo-Hyun, won the 1997 and 2002 presidential elections. In Taiwan, Chén Shuǐbiăn was elected president in 2000 and 2004, ending the more than 50-year domination of the Chinese Nationalist Party.

With regard to Southeast Asia, in Singapore the presidency became a popularly elected office in 1993, following major political changes and amendments to the constitution in 1991. In Malaysia, Mahathir bin Mohamad, leader of the United Malays National Organization, won five consecutive general elections and served as prime minister from 1981 until 2003. The office was peacefully transferred to his successors, Abdullah Ahmad Badawi (2003-2009) and the incumbent, Mohd Najib Abdul Razak. In Thailand, popular protests by the People's Alliance for Democracy occurred in 2006, with the result that Thaksin Shinawatra, who had been elected in 2001, was deposed by a military junta, which was later titled the Council for National Security. In Myanmar, opposition leader Aung San Suu Kyi was released from house arrest in 2010, and demands by citizens for democracy and liberty have since gradually increased.

With regard to Central Asia, in Uzbekistan and Kazakhstan, classified as hard authoritarian regimes, Islam Karimov and Nursultan Nazarbayev have served as presidents since independence from the Soviet Union was secured in 1990 and 1991 respectively. Citizens of the two countries enjoy few political rights or civil liberties.

In the Middle East, by 2011 the Arab Spring had reached Bahrain, Iran, Jordan, Kuwait, the United Arab Emirates, and Yemen (Guardian, 2011), yet this has not produced democratic 
regimes. Bengio (2012) has suggested that, to some extent, Turkey could be viewed as a Muslim democracy in an otherwise autocratic Muslim world. This has been a long process; democracy was nourished slowly within Turkish society, although Turkey was Western-oriented and more adaptive to democratic norms. Turkey was also able to develop a strong economy, which in turn enabled it to cultivate a civil society that developed alongside separation of religion and state. The ruling Islamist Justice and Development Party has, since 2002, managed to reduce the military's role in politics.

As far as economic capacity is concerned, Japan, South Korea, Singapore, Taiwan, and Turkey, often called the capitalist developmental states, experienced rapid economic development by the 1970s or 1980s (Caiden and Kim, 1999; Weiss, 2000). Many argue that this resulted from market-friendly policies, selective intervention to promote export growth and import substitution, professional and meritocratic bureaucracies, cooperation of government with business, high levels of human capital, efficient resource allocation, and reliance on public corporations, in line with principles of shared growth and economic nationalism (World Bank, 1993; Johnson, 1999; Woo-Cumings, 1999). Accordingly, industrial policy seemed to be compatible with market forces, transformative goals and institutions were aimed at upgrading the industrial economy, and revolutionary authority came from the state's achievements.

Economic capacity has also grown in the other countries over the last two decades. China has experienced economic growth since the market reforms of the early 1990s, and India has witnessed remarkable growth despite economic downturns across the continent. Malaysia, initiated a number of programs promoting rapid modernization and economic growth beginning in the 1980s with Mahathir bin Mohamad's New Economic Policy and Look-East doctrine. The Bumiputera policy, which aimed at raising the economic status of indigenous people, was also introduced around the same time. Under Thaksin Shinawatra, Thailand initiated massive programs of economic development, including infrastructure investment, poverty alleviation, and universal healthcare. Economic growth has been continuously emphasized in Kazakhstan and Uzbekistan following independence, while the United Arab Emirates' economic growth is symbolized by the city of Dubai.

Economic liberalization has also been undertaken with the aim of reinforcing economic capacity. Indonesia, Malaysia, South Korea, Thailand and the Philippines all initiated liberalization reforms to different degrees at various points from the 1980s onwards. These efforts were often influenced at least in part by international institutions. In the case of South Korea, economic liberalization efforts, beginning in the early 1980s, were increased in line with 
the neoliberal paradigm of the Organization for Economic Co-Operation and Development (OECD) after South Korea's accession in 1996 (Kim, 2000).

In the Middle East, the oil producing states have largely avoided liberalizing reforms. Yet, among other nations, Turkey underwent liberalization from the early 1980s, particularly under prime minister Turgut Özal, and Jordan has undergone rapid privatization and liberalization of the economy since around the year 2000. In central Asia, Turkmenistan has undertaken only limited reforms, while Uzbekistan has appeared more willing to liberalize. Kazakhstan and Kyrgystan, however, were quick to introduce reforms for privatization and liberalization in the early 1990s. In the case of the latter country, this has been influenced by the openness of the leadership to the ideas of Western market economies.

However the relationship of liberalization with growth has been debated. For example, it has been argued that weak regulation of capital flows, most notably in Indonesia, South Korea, and Thailand not only destroyed the conditions for growth, but also undermined the very basis of their economies, leading to the Asian financial crisis (Chang, 2000; Weiss, 2000). Following the crisis, calls were made for a new financial architecture and limits to be placed on financial liberalization (Stiglitz, 2003). More generally, in the context of the global economic crisis, which began in 2008, Wade (2010) has emphasized that liberalizing markets is not necessary for economic growth over the long term in low-income countries.

\section{Increases in State Capacity}

\section{Political Capacity}

Political capacity seemed to improve slightly in the 40 countries between 2002 and 2012. The average EMPINX score rose slightly from 3.52 in 2002 to 3.57 in 2010 at the same time as variation in scores between the countries decreased from a standard deviation of 3.35 to one of 2.33. As highlighted in Appendix 1, the highest scores for 2002 were awarded to Japan and Mongolia (10.0), followed by Israel and the Philippines (9.0). In 2010 Japan (9.29) and Mongolia were joined at the top of the table by South Korea and Taiwan (both 7.86). In 2002, the lowest score (0.0) was held by China, Iran, Iraq, North Korea, Laos, Myanmar, Oman, Turkmenistan, Uzbekistan, Vietnam, and Yemen. In 2010, the foot of the table was occupied by Iran, Qatar, Vietnam, and Yemen (all 0.71), though figures were not reported for China, North Korea, Myanmar, Saudi Arabia, Turkmenistan, and Uzbekistan.

There was also a general improvement in the DI, as the average score decreased from 4.85 in 2003 to 4.73 in 2012 (a lower score represents a better performance), but the variation in scores rose slightly, from 1.68 to 1.71 . In 2003, the best score was held by Japan (1.5), followed 
by Israel, Mongolia, South Korea, and Taiwan (2.0), and by 2012 the best score was held by Israel, Japan, South Korea, and Taiwan (1.5). The worst score (7.0) was held by Iraq, North Korea, Myanmar, Saudi Arabia, and Turkmenistan in 2003, and by North Korea, Saudi Arabia, Turkmenistan, and Uzbekistan in 2012.

There were not improvements in all areas of political capacity, however. As highlighted in table 1, the average score in the PFI increased from 64.03 in 2003 to 65.70 in 2012, which might imply a slight downturn in freedom of expression in the press.

\section{Economic Capacity}

The importance of economic capacity and particularly economic growth has long been emphasized for national development. On the whole, there was a general improvement in economic capacity between 2002 and 2012. The average EFI score increased from 55.05 in 2002 to 58.32 in 2012. The highest score in 2002 was held by Singapore (88.58), followed by Bahrain (77.74), the United Arab Emirates (70.56), Taiwan (70.04), Japan (66.97), South Korea (66.14), and Cambodia (65.04). In 2012, Qatar (71.3) and Jordan (69.9) entered the top seven, pushing out Cambodia and the United Arab Emirates.

The average score in the OPENK rose more remarkably, from 92.05 in 2000 to 103.81 in 2010. The top seven countries in terms of trade openness in 2000 were Singapore, Malaysia, Turkmenistan, Bahrain, Iraq, Thailand, and Jordan, while in 2010 they were Singapore, Malaysia, Tajikistan, Cambodia, Vietnam, the United Arab Emirates, and Thailand.

Average GDPC improved from US\$13,033 in 2002 to US\$14,845 in 2011. The top seven countries in 2002 were Qatar, the United Arab Emirates, Brunei, Singapore, Kuwait, Japan, and Bahrain. In 2011 they were Qatar, Singapore, Kuwait, Brunei, the United Arab Emirates, Japan, and South Korea. All of these reflect improvements in economic capacity across the continent.

[Insert table 1 about here.]

\section{Changes in Quality of Government}

Along with increased political and economic capacity, there have been improvements in quality of government in many Asian countries. However, as shown in Appendix 2, average scores in all categories held negative values in both 2002 and 2010. It is also important to note that while some measures have improved, others have decreased. Government effectiveness (GEE) and rule of law (RLE) increased more during the last decade than corruption control (CCE) and political stability (PSE). Between 2002 and 2010, GEE increased in 27 countries 
and decreased in just 13, while RLE increased in 22 countries and decreased in 18. By comparison, CCE increased in only 12 countries and decreased in 28; and PSE increased in 17 countries. The 40-country average for GEE, which held the highest mean score of the four indicators, improved from -0.19 in 2002 to -0.1 in 2010, but it decreased in the other three categories of CCE $(-0.23$ to -0.31$)$, RLE $(-0.23$ to -0.27$)$, and PSE $(-0.37$ to -0.51$)$. The variation in scores between the countries was largest for RQE in 2002 with a standard deviation of 1.00, and PSE (1.07) in 2010.

Most of the highest individual scores in 2002 were held by Singapore: 2.35 in CCE, 1.84 in GEE, 1.16 in PSE, and 1.45 in RLE. The lowest scores in 2002 went to Afghanistan for CCE (-1.43), PSE (-2.32) and RLE (-1.78), and North Korea for GEE (-2.32). In 2010, the highest PSE score was held by Brunei (1.24), while the highest score for each of the other measures was still held by Singapore (2.18 in CCE, 2.25 in GEE, and 1.69 in RLE). The lowest scores in 2012 were held by Myanmar ( -1.68 in CCE), North Korea ( -1.87 in GEE), Pakistan ( -2.70 in PSE), and Afghanistan (-1.90 in RLE).

Deviation from the mean differed among the four indicators. In both 2002 and 2010, it was large for PSE but small for RLE. CCE and GEE fell between these two extremes. Generally, in both years, quality of government tended to be higher in countries where a certain level of economic capacity has been reached: Brunei, Israel, Japan, Malaysia, Qatar, Singapore, South Korea, Taiwan, and the United Arab Emirates.

\section{THE EFFECTS OF POLITICAL AND ECONOMIC CAPACITY ON QUALITY OF GOVERNMENT IN ASIAN COUNTRIES}

\section{Empirical Results}

\section{The Effects of State Capacity on Quality of Government}

The effects of political and economic capacities on quality of government were analyzed using four dependent variables. Each dependent variable was regressed to the six independent variables, and the results are displayed in table 2 . The explanatory power of the results are good, although political stability is lower than the others $\left(\mathrm{R}^{2}=.461\right)$. As such, caution is needed when interpreting the results for this variable. The Durbin Watson statistics are close to 2 for all variables, suggesting that auto-correlation is not an issue. 
Corruption Control: Each of the three economic capacity variables had a statistically significant, positive effect on corruption control; EFI had the biggest effect (.022), whereas none of the political capacity variables had a statistically significant effect.

Government Effectiveness: DI (-.226), which is inversely measured, had a statistically significant negative effect on GEE. This means that as the degree of democracy increases, government effectiveness may also rise. However, unexpectedly EMPINX (-.068) had a negative, albeit relatively smaller impact on GEE. In addition, the three economic capacity variables (EFI, OPENK, and GDPC) also had a positive effect.

Political Stability: Two economic capacity variables (OPENK and GDPC) had a positive effect on political stability, whereas none of the political capacity variables had a statistically significant effect.

Rule of Law: The economic capacity variables of EFI and GDPC had a positive effect on rule of law, while none of the political capacity variables had a statistically significant effect.

[Insert table 2 about here.]

To sum up, when considering the aggregate results across the 40 countries, economic capacity variables were found to have a significant effect on four governance indices, while political capacity variables only had a statistically significant impact on one variable (GEE). It is worth noting, however, that the effect of the political capacity variable (DI) was strongest. Still, analyzing the aggregate results does not allow us to distinguish whether the effects of the independent variables on quality of government differ according to the level of economic development. As such, the next step was to divide the countries into two groups, developed and developing economies, in terms of GDPC.

\section{Differences in the Effects on Developed and Developing Economies}

A line can be drawn between the effects of state capacity variables on quality of government in developed and developing countries. As highlighted in table 3, political variables have a statistically significant impact on four dependent variables in the developed countries and in two in the developing countries, whereas economic variables influence four dependent variables in both the developed and developing countries. It could be inferred from these results that economic capacity leads to improvements in the quality of government, but that political democracy also leads to improvements and these effects differ depending on the degree of economic growth that has been achieved. 
Corruption Control: For the variables that affect CCE, there is a clear division between developed and developing countries. In the developed countries, PFI (-.022) has a statistically significant effect, as do EFI (.029) and GDPC (.459) (As unstandardized coefficients of the GDPC variable are too small in value to explain the relationships clearly, standardized coefficients, which are underlined, are presented hereafter). By comparison, in the developing countries, GDPC (.698) is the only variable with a statistically significant effect. This might imply that economic capacity has a positive effect on corruption control in both categories, whereas political democracy has a positive impact on it once countries have achieved a certain degree of economic growth.

Government Effectiveness: There is also a clear difference regarding effects upon GEE between developed and developing countries. In the developed countries, DI (-.250), EFI (.032), and GDPC (.263) significantly affect it, while in the developing countries, only GDPC (.677) significantly affects it. This implies that, in the developed countries both political and economic capacity have a positive impact on GEE, but in the developing countries only economic capacity has a positive impact.

Political Stability: The line between the two groups of countries is less distinct for PSE. In the developed countries, GDPC (.393) and DI (.451) have a significant impact, although the effects of the latter are inverse. In the developing countries, EMPINX, OPENK, and GDPC (.241, .009, and .631) affect it positively, but EFI (-.067) inversely. These results show that economic growth positively affects political stability in both groups, but that economic liberty has a negative effect in the developing countries. Increased political capacity reduced political stability in the developed countries, while civil empowerment had a positive effect in the lesser developed countries. However, these results need to be interpreted with caution, as the goodness-of-fit of these two models is somewhat lower than in the others $\left(\mathrm{R}^{2}=.482\right.$ and .489$)$.

Rule of Law: There are clear differences between developed and developing countries in terms of the effects upon RLE. In the developed countries, PFI (-.019), EFI (.034), and GDPC (.265) all have significant effects, while in the developing countries, EMPINX (.108) and GDPC (.649) are significant influences. These results imply that state political capacity may affect the rule of law in both developed and developing countries, albeit through different variables. Economic capacity can be seen to have a more straightforward positive affect upon RLE in both development categories.

[Insert table 3 about here.] 


\section{Implications of the Results}

Although state capacity in Asia varies to a great extent from country to country, the results indicate that economic capacity affects quality of government in both developed and developing countries, while the influence of political capacity can be felt more after a degree of economic development is attained. Among the economic capacity variables, EFI had a positive effect on three of the quality of government variables (corruption control, government effectiveness, and rule of law). However, in developing countries, the effects were negative. This finding can be interpreted as reinforcing the argument that economic liberalization can have negative consequences if undertaken too soon in a nation's development (Chang, 1999). The results for GDPC are more straightforward to interpret, and support the findings of Knack (2001) and Holmberg et al. (2009): economic growth can directly enhance quality of government. The results for trade openness are broadly consistent with those of Bäck and Hadenius (2008) and Charron and Lapuente (2010), although the effects are relatively modest and do not have as much impact as the other two economic variables.

The results also suggest that political capacity influences quality of government, particularly once a certain degree of economic capacity is achieved. The Democracy Index had the most impact out of the political variables, particularly in developed countries. The results reveal that a reduction in democracy is bad for government effectiveness, but may enhance political stability, in the short term at least. While a degree of caution is needed, there is some similarity with Bäck and Hadenius' (2008) finding that administrative capacity can be maintained to some extent by control from above. The findings thus indicate that the quality of government variables do not always respond in a uniform manner to the independent variables. Significantly, these effects have not been considered in the literature, due to overlapping definitions of state capacity and quality of government, and the exclusion of political stability from measures of quality of government.

Interestingly, the negative impact of EMPINX upon government effectiveness suggests that there is not a straightforward relationship between civil empowerment and the quality of public services and the bureaucracy. The positive impact upon political stability and rule of law in developing countries is notable, however, and indicates that there are quality of government benefits for increased political capacity even before economic capacity has been consolidated. Thus, political capacity is not something which should be pursued only after a degree of economic development. Rather, it can be pursued concurrently, and there are benefits for those countries which do so. As the effects of press freedom were most strongly felt by developed 
economies on corruption and rule of law, this indicates that press efforts to root out corruption and report crime are more likely to be successful after a degree of economic development has been achieved.

The results have clearly shown political and economic capacity to impact upon quality of government in different ways according to the level of economic development. This does not mean that political capacity is less important in developing countries or that economic capacity is less important in developed countries. Rather, it suggests that, once economic capacity reaches a certain level, political capacity takes on a new significance in relation to quality of government. The results thus share some similarities with those of La Porta et al. (1999) and Charron and Lapuente (2010) in the sense that political capacity can promote improved quality of government when building upon solid state economic capacity. More generally, the results point to the benefits of improved state capacity for sustained development in Asia (Evans, 1997). Although democracy has only begun to be consolidated in the region relatively recently, it can prompt improvements in the quality of government, as can increased economic capacity.

\section{CONCLUSIONS}

This study has attempted to address two main issues in the quality of government literature, firstly, it has sought to contribute to discussions over the conceptualization and measurement of quality of government, and secondly, it has attempted to fill a gap in the quality of government literature by analyzing Asia, an area which has been subject to enormous changes in recent decades. In doing so, we have approached quality of government from an outputs perspective in order to test the effects of state political and economic capacities on corruption

control, government effectiveness, political stability, and rule of law. Our findings therefore have implications which go beyond narrow economic efficiency approaches to quality of government, particularly as we have also considered corruption control and political stability factors, which have been excluded from some studies. Thus, this study has theoretical implications which go beyond the boundaries of the Asian continent.

The results confirm that economic capacity influences quality of government in Asian countries, but also that political capacity can have a positive impact. The effects of state capacities differ, however, depending on the level of economic development. In the developing countries, economic capacity had a significant impact on all four of the quality-of-government indices, whereas political capacity had a significant influence upon only political stability and rule of law. In comparison, the impact of political factors on quality of government is greater 
in developed countries. While the results indicate that there are particular benefits to be gained from improving political capacity once states have achieved a degree of economic development, the effects on political stability and rule of law in developing countries make it clear that efforts to improve political capacity should not be postponed. These findings can clearly contribute to the literature on state capacity and quality of government.

There are some limitations to the present study, however. In particular, only a relatively limited number of cases have been examined, and the same year statistics were not available for all of the variables. Nevertheless, we have suggested a new way of measuring quality of government which includes the factors of corruption control and political stability, and allows the relationships with state capacities to be tested, then employed this model in an underresearched area in quality of government terms. Further studies could use this model to examine the extent to which, and in what ways, political and economic capacity can affect quality of government both inside and outside of Asia. Such research could contribute to improvements at a practical level for governments and citizens alike.

\section{REFERENCES}

Adserà A, Boix C, Payne M. 2003. Are You Being Served? Political Accountability and Quality of Government. Journal of Law, Economics \& Organization, 19(2): 445-490.

Amsden AH. 1992. Asia's Next Giant: South Korea and Late Industrialization. Oxford: Oxford University Press.

Bäck H, Hadenius A. 2008. Democracy and State Capacity: Exploring a J-Shaped Relationship. Governance, 21(1), 1-24.

Bengio O. 2012. Are Iraq and Turkey Models for Democratization? Middle East Quarterly, 19(3): 5362.

Bueno de Mesquita B, Smith A, Siverson RM, Morrow JD. 2003. The Logic of Political Survival. MIT Press: Cambridge, MA.

Caiden GE, Kim BW, ed. 1999. A Dragon's Progress: Development Administration in Korea. Kumarian Press: Hartford, CT.

Chang HJ. 1999. The Economic Theory of the Developmental State. In M Woo-Cumings (ed.) The Developmental State, pp. 182-199. Cornell University Press: New York.

Chang HJ. 2000. The Hazard of Moral Hazard: Untangling the Asian Crisis. World Development, 28(4): $775-788$.

Charron N, Lapuente V. 2010. Does Democracy Produce Quality of Government? European Journal of Political Research, 49: 443-470. 
Cingranelli DL, Richards DL. 2011. Short Variable Descriptions for Indicators in the CIRI Human Rights Dataset, available at http://www.humanrightsdata.org/documentation.asp [accessed on 3 Aug 2012].

Cingranelli DL, Richards DL. 2012. Human Rights Data Project, available at http://www.humanrightsdata.org [accessed on 3 Aug 2012].

Deyo FC. (Ed.). 1987. The Political Economy of the New Asian Industrialism. Ithaca: Cornell University Press.

Dunleavy P, Hood C. 1994. From Old Public Administration to New Public Management. Public Money \& Management, 14(3): 9-16.

Dunleavy P, O'Leary B. 1987. Theories of the State: the Politics of Liberal Democracy. Macmillan Education Publications: Basingstoke.

Evans PB. 1997. The Eclipse of the State: Reflections on Stateness in an Era of Globalization. World Politics, 50(1): 62-87.

Fogel K. 2006. Oligarchic Family Control, Social Economic Outcomes, and the Quality of Government. Journal of International Business Studies, 37(5): 603-622.

Freedom House, http://www.freedomhouse.org/reports [accessed on 3 August 2012].

Frischtak, LL. 1994. Governance Capacity and Economic Reform in Developing Countries, World Bank Technical Paper 254. Washington, DC: World Bank.

Goel RK, Nelson MA. 2005. Economic Freedom Versus Political Freedom: Cross-Country Influences on Corruption. Australian Economic Papers, 44(2): 121-133.

Grindle MS. 1996. Challenging the State: Crisis and Innovation in Latin America and Africa. Cambridge: Cambridge University Press.

Guardian 2011. Arab Spring: An Interactive Timeline, available at http://www.guardian.co.uk/world/ interactive/2011/mar/22/middle-east-protest-interactive-timeline [accessed on 20 August 2012].

Hadenius A, Teorell J. 2005. Assessing Alternative Indices of Democracy. C\&M Working Paper 6, IPSA, available at http://www.concepts-methods.org/working_papers/ 20050812_16_PC\%206\%20Hadenius\%20\&\%20Teorell.pdf [accessed on7 August 2012].

Hamilton N, Kim EM. 1993. Economic and Political Liberalisation in South Korea and Mexico. Third World Quarterly, 14(1): 109-136.

Hanousek J, Palda F. 2004. Quality of Government Services and the Civic Duty to Pay Taxes in the Czech and Slovak Republics, and Other Transition Countries. Kyklos, 57(2): 237-252.

Henderson J. 1999. Uneven Crises: Institutional Foundations of East Asian Economic Turmoil. Economy and Society, 28(3): 327-368.

Heritage Foundation, http://www.heritage.org/index/ [accessed on 3 August 2012].

Holmberg S, Rothstein B, Nasiritousi N. 2009. Quality of Government: What You Get. Annual Review of Political Science, 12: 135-161.

Jessop B. 2007. State Power. Cambridge: Polity. 
Johnson C. 1999. The Developmental State: Odyssey of a Concept. In M Woo-Cumings (ed.), The Developmental State, pp. 32-60. Cornell University Press: New York.

Kim, BK. 2000. Electoral Politics and Economic Crisis, 1997-1998. In L Diamond, BK Kim (ed.), Consolidating Democracy in South Korea (pp. 173-201). Boulder, CO: Lynne Rienner.

Kim, EM. 1997. Big Business, Strong State: Collusion and Conflict in South Korean Development, 1960-1990. Albany: State University of New York Press.

Knack S. 2001. Aid Dependence and the Quality of Governance: Cross-country Empirical Tests. Southern Economic Journal, 68(2): 310-329.

La Porta R, López-de-Silanes F, Shleifer A, Vishny R. 1999. The Quality of Government. Journal of Law, Economics and Organization, 15(1): 222-279.

Laski HJ. 2008. The State in Theory and Practice. Brunswick, NJ: Transaction.

Lijphart A. 1999. Patterns of Democracy: Government Forms and Performance in Thirty-Six Countries. Yale University Press: New Haven and London.

Milward HB, Provan K. 2000. Governing the Hollow State. Journal of Public Administration Research and Theory, 10(2):359-79.

Oppenheimer F. 1908. The State. Indianapolis, IN: Bobbs-Merrill.

Osborne D, Gaebler T. 1992. Reinventing Government. Reading, MA: Addison-Wesley.

Osborne SP, McLaughlin K. 2002. The New Public Management in Context. In K McLaughlin, SP Osborne, E Ferlie (ed.) New Public Management: Current Trends and Future Prospective, pp.714. Routledge: London.

Penn World Table Version 2012, http://pwt.econ.upenn.edu/php_site/pwt_index.php [accessed on 3 August 2012].

Pollitt C. 2011. Moderations in All Things: International Comparisons of Governance Quality. Financial Accountability and Management, 27(4): 437-457

Przeworski A, Alvarez ME, Cheibub JA, Fernando L. 2000. Democracy and Development: Political Institutions and Material Well-Being in the World: 1950-1990. Cambridge University Press: New York.

Rhodes RAW. 2000. Governance and Public Administration, in J Pierre, ed., Debating Governance: Authority, Steering, and Democracy. Oxford: University of Oxford Press. 54-90.

Rothstein B. 2003. Social Capital, Economic Growth and Quality of Government: The Causal Mechanism. New Political Economy, 8(1): 49-71.

Rothstein B, Teorell J. 2008. What is Quality of Government? A Theory of Impartial Government Institutions. Governance, 21(2): 165-190.

Rueschemeyer D, Evans PB. 1985. The State and Economic Transformation: Towards an Analysis of the Conditions Underlying Effective Intervention. In PB Evans, D Rueschemeyer, T Skocpol (ed.) Bringing the State Back In, pp.44-77. Cambridge University Press: Cambridge. 
Schmitt C. 1928/2007. Constitutional Theory, translated by Jeffrey Seitzer. Durham, NC: Duke University Press.

Skocpol T. 1985. Bringing the State Back In: Strategies of Analysis in Current Research. In PB Evans, D Rueschemeyer, T Skocpol (ed.), Bringing the State Back In, pp. 3-37. Cambridge University Press: Cambridge.

Stiglitz, J. E. 2003. Globalization and its Discontents. New York: WW Norton \& Company.

Teorell J, Samanni M, Holmberg S, Rothstein B. 2012a. The Quality of Government Basic Dataset Made from The QoG Standard Dataset Version 6Apr11. University of Gothenburg, Quality of Government Institute: Gothenburg, Sweden, available at http://www.qog.pol.gu.se [accessed on 8 July 2012].

Teorell J, Samanni M, Holmberg S, Rothstein B. 2012b. The QOG Basic Dataset Codebook. University of Gothenburg, Quality of Government Institute: Gothenburg, Sweden, available at http://www.qog.pol.gu.se [accessed on 8 July 2012].

Treisman D. 2002. Decentralization and the Quality of Government. Unpublished paper, Department of Political Science, University of California, Los Angeles, available at http://www.sscnet.ucla.edu/polisci/faculty/treisman/Papers/DecandGovt.pdf [accessed on 24 August 2012].

Vanhanen T. 2000. A New Dataset for Measuring Democracy, 1810-1998. Journal of Peace Research, 37(2): 252-265.

Vanhanen T. 2003. Democratization: A Comparative Analysis of 170 Countries. Routledge: London.

Wade R. 2010. After the Crisis: Industrial Policy and the Developmental State in Low-Income Countries. Global Policy, 1(2), 150-161.

Weber, M. 1987. Politics as Vocation, in W Runciman, ed., Max Weber. Selections in Translation, translated by E Mathews. Cambridge: Cambridge University Press, 212-225.

Weiss L. 2000. Developmental States in Transition: Adapting, Dismantling, Innovating, not 'Normalizing'. The Pacific Review, 13(1): 21-55.

White G. 1995. Towards a Democratic Developmental State. IDS bulletin, 26(2), 27-36.

Woo-Cumings M. 1999. Introduction: Chalmers Johnson and the Politics of Nationalism and Development. In M Woo-Cumings (ed.), The Developmental State, pp. 1-31. Cornell University Press: New York.

World Bank 1989. Sub-Saharan Africa: From Crisis to Sustainable Growth. Washington, DC: World Bank.

World Bank. 1993. The East Asian Miracle: Economic Growth and Public Policy. Oxford University Press: Oxford.

World Bank Governance Index, http://info.worldbank.org/governance/wgi/index.asp [accessed on 2 August 2012]. 
World Development Index (World Bank), http://data.worldbank.org/data-catalog [accessed on 6 August 2012]. 


\section{TABLES}

[Table 1] State Capacities and Quality of Government in 40 Asian Countries

\begin{tabular}{|c|c|c|c|c|c|c|c|}
\hline Variable & Index & Year & $\mathrm{N}$ & Minimum & Maximum & Mean & $\mathrm{SD}$ \\
\hline \multirow{10}{*}{$\begin{array}{l}\text { Quality of } \\
\text { government }\end{array}$} & \multirow[t]{2}{*}{ WBGI_CCE } & 2002 & 40 & -1.43 & 2.35 & -0.23 & 0.907 \\
\hline & & 2010 & 40 & -1.68 & 2.18 & -0.32 & 0.959 \\
\hline & \multirow[t]{2}{*}{ WBGI_GEE } & 2002 & 40 & -1.92 & 1.84 & -0.19 & 0.903 \\
\hline & & 2010 & 40 & -1.87 & 2.25 & -0.10 & 0.953 \\
\hline & \multirow{2}{*}{ WBGI_PSE } & 2002 & 40 & -2.32 & 1.16 & -0.37 & 0.959 \\
\hline & & 2010 & 40 & -2.70 & 1.24 & -0.51 & 1.070 \\
\hline & \multirow[t]{2}{*}{ WBGI_RLE } & 2002 & 40 & -1.78 & 1.45 & -0.23 & 0.894 \\
\hline & & 2010 & 40 & -1.90 & 1.69 & -0.27 & 0.911 \\
\hline & \multirow[t]{2}{*}{ WBGI(mean) } & 2002 & 40 & -1.79 & 1.70 & -0.26 & 0.830 \\
\hline & & 2010 & 40 & -1.90 & 1.81 & -0.30 & 0.892 \\
\hline \multirow{3}{*}{$\begin{array}{l}\text { Political capacity } \\
\text { Civil empowerment }\end{array}$} & \multirow{3}{*}{ EMPINX } & & & & & & \\
\hline & & 2002 & 40 & 0 & 10 & 3.53 & 3.35 \\
\hline & & 2010 & 34 & 0.71 & 9.29 & 3.57 & 2.33 \\
\hline \multirow[t]{2}{*}{ Democracy } & \multirow[t]{2}{*}{ DI (mean) } & 2003 & 40 & 1.5 & 7.0 & 4.85 & 1.68 \\
\hline & & 2012 & 40 & 1.5 & 7.0 & 4.73 & 1.71 \\
\hline \multirow[t]{2}{*}{ Press freedom } & \multirow[t]{2}{*}{ PFI } & 2003 & 40 & 17 & 96 & 64.03 & 20.35 \\
\hline & & 2012 & 40 & 22 & 97 & 65.70 & 20.01 \\
\hline \multirow{3}{*}{$\begin{array}{l}\text { Economic capacity } \\
\text { Economic freedom }\end{array}$} & \multirow{3}{*}{ EFI } & & & & & & \\
\hline & & 2002 & 36 & 4.44 & 88.58 & 55.05 & 14.30 \\
\hline & & 2012 & 37 & 1.0 & 87.5 & 58.32 & 14.01 \\
\hline \multirow[t]{2}{*}{ Trade openness } & \multirow[t]{2}{*}{ OPENK } & 2000 & 39 & 0.62 & 339.80 & 92.05 & 59.53 \\
\hline & & 2010 & 38 & 29.31 & 409.22 & 103.81 & 65.91 \\
\hline \multirow[t]{2}{*}{ Economic growth } & \multirow[t]{2}{*}{ GDPC } & 2002 & 37 & 568.55 & $67,945.32$ & $13,033.84$ & $18,064.63$ \\
\hline & & 2011 & 37 & $1,082.95$ & $77,987.08$ & $14,845.60$ & $18,192.07$ \\
\hline
\end{tabular}

Note: WBGI (mean) refers to a mean of four estimates of the World Bank Governance Index; DI (mean) refers to a mean of two estimates of Freedom House's Democracy Index.

Sources: World Bank Governance Index for the 2002 and 2010 WBGI; Teorell et al. (2012a) and Cingranelli and Richards (2012) for the 2002 and 2010 EMPINX; Teorell et al. (2012a) and Freedom House for the 2003 and 2012 DI and PFI; Teorell et al. (2012a) and Heritage Foundation for the 2002 and 2012 EFI; Penn World Table for the 2000 and 2010 OPENK; and World Development Index for the 2002 and 2011 GDPC. 
[Table 2] Effects of State Capacity Variables on Quality of Government

\begin{tabular}{|c|r|r|r|r|}
\hline Variables & $\begin{array}{r}\text { WBGI_CCE } \\
(\mathrm{N}=63)\end{array}$ & $\begin{array}{r}\text { WBGI_GEE } \\
(\mathrm{N}=63)\end{array}$ & $\begin{array}{c}\text { WBGI_PSE } \\
(\mathrm{N}=63)\end{array}$ & $\begin{array}{c}\text { WBGI_RLE } \\
(\mathrm{N}=63)\end{array}$ \\
\hline (constant) & -.879 & -.856 & $-2.060^{*}$ & $-1.228^{*}$ \\
EMPINX & -.050 & $-.068^{* *}$ & .081 & -.040 \\
ĐI & -.034 & $-.226^{* *}$ & .280 & -.113 \\
PFI & -.014 & -.003 & -.014 & -.009 \\
EFI & $.022^{* *}$ & $.032^{* * *}$ & .003 & $.034^{* * *}$ \\
OPENK & $.003^{* *}$ & $.002^{*}$ & $.004^{* *}$ & .001 \\
GDPC & $2.689 \mathrm{E}-5^{* * *}$ & $1.467 \mathrm{E}-5^{* * *}$ & $2.542 \mathrm{E}-5^{* * *}$ & $1.766 \mathrm{E}-5^{* * *}$ \\
& $(.542)^{* * *}$ & $(.331)^{* * *}$ & $(.486)^{* * *}$ & $(.393)^{* * *}$ \\
\hline R & 0.785 & 0.788 & 0.461 & 0.783 \\
DW & 1.944 & 2.367 & 1.683 & 2.109 \\
F & $34.056^{* * *}$ & $34.657^{* * *}$ & $7.995^{* * *}$ & $33.764^{* * *}$ \\
\hline
\end{tabular}

$* \mathrm{p}<0.1, * * \mathrm{p}<0.05, * * * \mathrm{p}<0.01$

Note1: The two variables crossed out in the first column indicate they are inversely measured.

2: Unstandardized coefficients are presented. For GDPC, standardized coefficients are also presented (in parentheses). 
[Table 3] Differences in the Effects of State Capacity Variables on Quality of Government between the Developed and Developing Countries

\begin{tabular}{|c|c|c|c|c|c|c|c|c|}
\hline \multirow[b]{2}{*}{ Variables } & \multicolumn{2}{|c|}{ WBGI_CCE } & \multicolumn{2}{|c|}{ WBGI_GEE } & \multicolumn{2}{|c|}{ WBGI_PSE } & \multicolumn{2}{|c|}{ WBGI_RLE } \\
\hline & $\begin{array}{l}\text { Developed } \\
(\mathrm{N}=33)\end{array}$ & $\begin{array}{c}\text { Developing } \\
(\mathrm{N}=30)\end{array}$ & $\begin{array}{l}\text { Developed } \\
(\mathrm{N}=33)\end{array}$ & $\begin{array}{l}\text { Developing } \\
(\mathrm{N}=30)\end{array}$ & $\begin{array}{l}\text { Developed } \\
(\mathrm{N}=33)\end{array}$ & $\begin{array}{l}\text { Developing } \\
(\mathrm{N}=30)\end{array}$ & $\begin{array}{c}\text { Developed } \\
(\mathrm{N}=33)\end{array}$ & $\begin{array}{l}\text { Developing } \\
(\mathrm{N}=30)\end{array}$ \\
\hline (constant) & -1.219 & -.481 & -1.073 & -.514 & $-3.117^{* *}$ & -1.501 & -1.066 & -1.235 \\
\hline EMPINX & -.028 & .082 & -.008 & .037 & .131 & $.241^{* *}$ & -.013 & $.108^{*}$ \\
\hline DI & .088 & .116 & $-.250^{*}$ & .087 & $.451^{*}$ & .380 & .033 & .029 \\
\hline PFI & $-.022^{*}$ & -.008 & .004 & -.012 & -.017 & -.006 & $-.019^{* *}$ & .001 \\
\hline EFI & $.029^{* *}$ & -.025 & $.032^{* * *}$ & -.006 & .018 & $-.067^{* *}$ & $.034^{* * *}$ & -.012 \\
\hline OPENK & .002 & .000 & .002 & -.001 & .002 & $.009^{* *}$ & .001 & -.002 \\
\hline GDPC & $2.053 \mathrm{E}-5^{* * *}$ & $.000^{* *}$ & $1.029 \mathrm{E}-5^{* *}$ & $.000^{* * *}$ & $1.607 \mathrm{E}-5^{* *}$ & $.000^{* *}$ & $9.548 \mathrm{E}-6^{* *}$ & $.000^{* * * *}$ \\
\hline & $(.459)^{* * * *}$ & $(.698)^{* *}$ & $(.263)^{* * *}$ & $(.677)^{* * * *}$ & $(.393)^{* *}$ & $(.631)^{* *}$ & $(.265)^{* *}$ & $(.649)^{* * *}$ \\
\hline $\mathrm{R}^{2}$ & 0.798 & 0.391 & 0.803 & 0.622 & 0.482 & 0.489 & 0.862 & 0.548 \\
\hline DW & 2.061 & 1.541 & 2.406 & 1.611 & 2.623 & 2.274 & 1.971 & 1.610 \\
\hline $\mathrm{F}$ & $17.159^{* * *}$ & $2.460^{*}$ & $17.626^{* * *}$ & $6.320^{* * *}$ & $4.033^{* * *}$ & $3.669^{* *}$ & $27.114^{* * *}$ & $4.656^{* * *}$ \\
\hline
\end{tabular}

$* \mathrm{p}<0.1, * * \mathrm{p}<0.05, * * * \mathrm{p}<0.01$

Note1: The two variables crossed out in the first column indicate they are inversely measured.

2: Unstandardized coefficients are presented For GDPC, standardized coefficients are also presented (in parentheses). 
[Appendix 1] Changes in Political and Economic Capacity in 40 Asian Countries between 2002 and 2012

\begin{tabular}{|c|c|c|c|c|c|c|c|c|c|c|c|c|}
\hline \multirow{2}{*}{$\begin{array}{r}\text { Variable } \\
\text { Year }\end{array}$} & \multicolumn{2}{|c|}{ EMPINX } & \multicolumn{2}{|c|}{ DI } & \multicolumn{2}{|c|}{ PFI } & \multicolumn{2}{|c|}{$\overline{E F I}$} & \multicolumn{2}{|c|}{ OPENK } & \multicolumn{2}{|c|}{ GDPC } \\
\hline & 2002 & 2010 & 2003 & 2012 & 2003 & 2012 & 2002 & 2012 & 2000 & 2010 & 2002 & 2011 \\
\hline \begin{tabular}{|l|} 
Afghanistan \\
\end{tabular} & 4 & 2.14 & 6.0 & 6.0 & 74 & 74 & & & 87.57 & 57.47 & 568.55 & $1,082.95$ \\
\hline \begin{tabular}{|l|} 
Bahrain \\
\end{tabular} & 4 & 2.86 & 5.0 & 6.0 & 68 & 84 & 77.74 & 75.2 & 156.48 & 138.26 & $25,964.58$ & $21,345.19$ \\
\hline \begin{tabular}{|l|} 
Bangladesh \\
\end{tabular} & 7 & 5.00 & 4.0 & 3.5 & 65 & 52 & 48.96 & 53.2 & 35.71 & 40.84 & $1,028.90$ & $1,568.44$ \\
\hline Bhutan & 2 & 2.86 & 5.5 & 4.5 & 70 & 58 & & 56.6 & 77.34 & 124.98 & $2,969.17$ & $5,095.60$ \\
\hline Brunei & 2 & 1.43 & 5.5 & 5.5 & 76 & 75 & & & 103.66 & 101.86 & $49,533.45$ & $45,506.59$ \\
\hline Myanmar & 0 & & 7.0 & 6.5 & 94 & 85 & 41.27 & 38.7 & 0.62 & & & \\
\hline Cambodia & 7 & 5.71 & 5.5 & 5.5 & 64 & 63 & 65.04 & 57.6 & 98.65 & 163.78 & $1,156.55$ & $2,079.99$ \\
\hline Sri Lanka & 8 & 2.14 & 3.5 & 4.5 & 52 & 72 & 60.88 & 58.3 & 76.10 & 66.57 & $3,105.69$ & $4,928.99$ \\
\hline \begin{tabular}{|l|} 
China \\
\end{tabular} & 0 & & 6.5 & 6.5 & 80 & 85 & 51.13 & 51.2 & 41.36 & 76.80 & $3,108.05$ & $7,404.31$ \\
\hline $\begin{array}{l}\text { Taiwan } \\
\end{array}$ & 8 & 7.86 & 2.0 & 1.5 & 24 & 25 & 70.04 & 71.9 & 111.71 & 127.58 & & \\
\hline India & 8 & 5.00 & 2.5 & 2.5 & 45 & 37 & 51.55 & 54.6 & 25.60 & 44.54 & $\begin{array}{l}1,817.84 \\
\end{array}$ & $3,203.00$ \\
\hline Indonesia & 3 & 5.00 & 3.5 & 2.5 & 56 & 49 & 52.59 & 56.4 & 52.68 & 61.65 & $2,767.89$ & $4,094.06$ \\
\hline Iran & 0 & 0.71 & 6.0 & 6.0 & 76 & 92 & 39.35 & 42.3 & 47.72 & 52.48 & $8,129.88$ & $10,462.27$ \\
\hline Iraq & 0 & 2.14 & 7.0 & 5.5 & 95 & 69 & & & 154.11 & 129.84 & $3,777.63$ & $3,412.16$ \\
\hline Israel & 9 & 3.57 & 2.0 & 1.5 & 27 & 30 & 63.96 & 67.8 & 85.97 & 83.17 & $22,042.87$ & $26,719.97$ \\
\hline Japan & 10 & 9.29 & 1.5 & 1.5 & 17 & 22 & 66.97 & 71.6 & 22.86 & 29.31 & $28,944.65$ & $30,660.40$ \\
\hline \begin{tabular}{|l|} 
Kazakhstan \\
\end{tabular} & 4 & 2.14 & 5.5 & 5.5 & 73 & 81 & 50.03 & 63.6 & 129.15 & 69.58 & $6,748.02$ & $11,567.68$ \\
\hline Jordan & 2 & 1.43 & 5.5 & 5.5 & 65 & 63 & 63.69 & 69.9 & 134.97 & 129.88 & $3,807.53$ & $5,268.58$ \\
\hline Korea, North & 0 & & 7.0 & 7.0 & 96 & 97 & 4.44 & 1.0 & & & & \\
\hline Korea, South & 8 & 7.86 & 2.0 & 1.5 & 29 & 32 & 66.14 & 69.9 & 61.14 & 92.06 & $20,598.07$ & $27,541.34$ \\
\hline Kuwait & 1 & 2.86 & 4.5 & 4.5 & 54 & 57 & 62.64 & 62.5 & 92.01 & 78.48 & $37,316.76$ & $47,935.04$ \\
\hline \begin{tabular}{|l|} 
Kyrgyzstan \\
\end{tabular} & 3 & 3.57 & 5.5 & 5.0 & 71 & 69 & 54.74 & 60.2 & 82.60 & 105.79 & $1,557.18$ & $2,125.85$ \\
\hline Laos & 0 & 2.14 & 6.5 & 6.5 & 80 & 84 & 36.88 & 50.0 & 66.01 & 63.94 & $1,468.58$ & $2,463.84$ \\
\hline \begin{tabular}{|l|} 
Malaysia \\
\end{tabular} & 4 & 2.14 & 5.0 & 4.0 & 71 & 63 & 58.67 & 66.4 & 200.89 & 195.01 & $10,329.29$ & $13,672.13$ \\
\hline Mongolia & 10 & 7.86 & 2.0 & 2.0 & 36 & 37 & 59.78 & 61.5 & 94.75 & 114.59 & $2,335.10$ & $4,178.29$ \\
\hline Oman & 0 & 2.14 & 5.5 & 5.5 & 73 & 71 & 61.77 & 67.9 & 84.63 & 101.29 & $20,588.21$ & $25,329.77$ \\
\hline \begin{tabular}{|l|} 
Nepal \\
\end{tabular} & 6 & 5.00 & 4.0 & 4.0 & 65 & 55 & 47.31 & 50.2 & 58.12 & 48.51 & 904.07 & $1,101.91$ \\
\hline \begin{tabular}{|l|} 
Pakistan \\
\end{tabular} & 2 & 2.14 & 5.5 & 4.5 & 58 & 63 & 55.47 & 54.7 & 26.93 & 30.52 & $1,866.51$ & $2,423.66$ \\
\hline \begin{tabular}{|l|} 
Philippines \\
\end{tabular} & 9 & 7.14 & 2.5 & 3.0 & 30 & 42 & 59.01 & 57.1 & 99.91 & 96.41 & $2,758.23$ & $3,630.94$ \\
\hline \begin{tabular}{|l} 
Qatar \\
\end{tabular} & 1 & 0.71 & 6.0 & 5.5 & 61 & 67 & 62.57 & 71.3 & 93.92 & 95.91 & $67,945.32$ & $77,987.08$ \\
\hline Saudi Arabia & 1 & & 7.0 & 7.0 & 80 & 84 & 57.23 & 62.5 & 73.38 & 89.38 & $19,107.35$ & $21,430.21$ \\
\hline Singapore & 4 & 4.29 & 4.5 & 4.0 & 66 & 67 & 88.58 & 87.5 & 339.80 & 409.22 & $37,814.22$ & $53,591.09$ \\
\hline \begin{tabular}{|l|} 
Vietnam \\
\end{tabular} & 0 & 0.71 & 6.5 & 6.0 & 82 & 84 & 43.92 & 51.3 & 104.63 & 152.02 & $1,784.37$ & $3,012.66$ \\
\hline Tajikistan & 2 & 2.86 & 5.5 & 5.5 & 76 & 79 & 43.08 & 53.4 & 125.26 & 177.09 & $1,143.79$ & $2,052.48$ \\
\hline \begin{tabular}{|l|} 
Thailand \\
\end{tabular} & 6 & 4.29 & 2.5 & 4.0 & 36 & 60 & 63.90 & 64.9 & 138.68 & 146.97 & $5,778.48$ & $7,633.01$ \\
\hline United Arab Emirates & 1 & 1.43 & 5.5 & 6.0 & 74 & 72 & 70.56 & 69.3 & 84.91 & 148.13 & $66,872.71$ & $42,293.05$ \\
\hline \begin{tabular}{|l|} 
Turkey \\
\end{tabular} & 5 & 4.29 & 3.5 & 3.0 & 55 & 55 & 50.86 & 62.5 & 40.32 & 46.83 & $9,565.59$ & $13,466.33$ \\
\hline \begin{tabular}{|l} 
Turkmenistan \\
\end{tabular} & 0 & & 7.0 & 7.0 & 92 & 96 & 46.96 & 43.8 & 167.18 & 116.30 & $3,169.15$ & $8,055.21$ \\
\hline \begin{tabular}{|l} 
Uzbekistan \\
\end{tabular} & 0 & & 6.5 & 7.0 & 86 & 95 & 37.97 & 45.8 & 43.41 & 74.75 & $1,725.40$ & $2,902.95$ \\
\hline Yemen & 0 & 0.71 & 5.5 & 6.0 & 69 & 83 & 46.07 & 55.3 & 69.07 & 62.95 & $2,152.59$ & $2,060.28$ \\
\hline
\end{tabular}

Note: Not all indices on which this study drew provided data for 2002 and 2012; in other cases, data from the closest available year were used. 
[Appendix 2] Changes in the Quality of Government in 40 Asian Countries between 2002 and 2012

\begin{tabular}{|c|c|c|c|c|c|c|c|c|c|c|}
\hline \multirow{2}{*}{$\begin{array}{c}\text { Variable } \\
\text { Year }\end{array}$} & \multicolumn{2}{|c|}{ Mean } & \multicolumn{2}{|c|}{ CCE } & \multicolumn{2}{|c|}{ GEE } & \multicolumn{2}{|c|}{ PSE } & \multicolumn{2}{|c|}{ RLE } \\
\hline & 2002 & 2010 & 2002 & 2010 & 2002 & 2010 & 2002 & 2010 & 2002 & 2010 \\
\hline \begin{tabular}{|l|} 
Afghanistan \\
\end{tabular} & -1.79 & -1.90 & -1.43 & -1.62 & -1.64 & \begin{tabular}{|l|}
-1.47 \\
\end{tabular} & -2.32 & -2.60 & -1.78 & -1.90 \\
\hline Bahrain & 0.56 & 0.24 & 0.75 & 0.25 & 0.56 & 0.59 & 0.18 & -0.34 & 0.77 & 0.45 \\
\hline \begin{tabular}{|l|} 
Bangladesh \\
\end{tabular} & $\begin{array}{ll}-0.97 \\
\end{array}$ & \begin{tabular}{|c|}
-1.01 \\
\end{tabular} & -1.18 & -0.99 & -0.72 & -0.84 & -1.07 & -1.42 & -0.90 & -0.77 \\
\hline Bhutan & 0.52 & 0.55 & 0.58 & 0.83 & 0.73 & 0.57 & 0.64 & 0.68 & 0.15 & 0.11 \\
\hline Brunei & 0.67 & 0.95 & 0.30 & 0.86 & 0.86 & 0.88 & 1.01 & 1.24 & 0.50 & 0.80 \\
\hline Myanmar & -1.40 & -1.54 & -1.22 & -1.68 & -1.31 & -1.67 & -1.48 & -1.29 & -1.60 & -1.50 \\
\hline \begin{tabular}{|c|} 
Cambodia \\
\end{tabular} & $\begin{array}{ll}-0.93 \\
\end{array}$ & \begin{tabular}{ll|}
-0.94 \\
\end{tabular} & -0.99 & -1.21 & -0.84 & $\begin{array}{l}-0.83 \\
\end{array}$ & -0.80 & $\begin{array}{l}-0.62 \\
\end{array}$ & -1.10 & -1.09 \\
\hline Sri Lanka & -0.22 & -0.38 & -0.25 & -0.43 & -0.08 & -0.17 & -0.84 & -0.83 & 0.30 & -0.09 \\
\hline China & -0.37 & -0.40 & -0.65 & -0.60 & -0.05 & 0.12 & -0.40 & -0.77 & -0.36 & -0.35 \\
\hline $\begin{array}{l}\text { Taiwan } \\
\end{array}$ & 0.75 & 0.94 & 0.63 & 0.75 & 0.82 & 1.21 & 0.64 & 0.79 & 0.90 & 1.01 \\
\hline India & -0.47 & -0.47 & -0.49 & -0.52 & -0.15 & -0.01 & -1.24 & -1.31 & -0.01 & -0.06 \\
\hline Indonesia & -1.04 & -0.61 & -1.14 & -0.73 & -0.47 & -0.20 & -1.61 & -0.89 & -0.95 & -0.63 \\
\hline Iran & -0.55 & $\begin{array}{ll}-0.97 \\
\end{array}$ & -0.23 & -0.88 & -0.52 & -0.52 & -0.81 & -1.57 & -0.66 & -0.90 \\
\hline \begin{tabular}{|l|} 
Iraq \\
\end{tabular} & -1.57 & -1.61 & -1.30 & -1.32 & -1.88 & -1.23 & -1.64 & -2.27 & -1.45 & -1.62 \\
\hline \begin{tabular}{|l|} 
Israel \\
\end{tabular} & 0.47 & 0.32 & 1.28 & 0.64 & 1.08 & 1.24 & -1.52 & -1.49 & 1.03 & 0.88 \\
\hline \begin{tabular}{|l|} 
Japan \\
\end{tabular} & 1.05 & 1.28 & 0.84 & 1.54 & 1.10 & 1.40 & 1.09 & 0.87 & 1.16 & 1.31 \\
\hline \begin{tabular}{|l|} 
Kazakhstan \\
\end{tabular} & \begin{tabular}{|l|l|}
-0.71 \\
\end{tabular} & -0.36 & -1.07 & -1.00 & -0.92 & -0.28 & 0.24 & 0.46 & -1.09 & -0.62 \\
\hline Jordan & -0.11 & 0.02 & -0.10 & 0.04 & 0.09 & 0.08 & -0.58 & -0.27 & 0.17 & 0.22 \\
\hline \begin{tabular}{|l} 
Korea, North \\
\end{tabular} & -0.99 & -1.24 & -1.17 & -1.34 & -1.92 & -1.87 & 0.21 & -0.45 & -1.08 & -1.30 \\
\hline \begin{tabular}{|l} 
Korea, South \\
\end{tabular} & 0.60 & 0.67 & 0.46 & 0.42 & 0.89 & 1.19 & 0.14 & 0.10 & 0.92 & 0.99 \\
\hline \begin{tabular}{|l|} 
Kuwait \\
\end{tabular} & 0.41 & 0.35 & 1.22 & 0.35 & 0.05 & 0.10 & -0.25 & 0.43 & 0.62 & 0.54 \\
\hline \begin{tabular}{|l|} 
Kyrgyzstan \\
\end{tabular} & -0.77 & -0.99 & -0.87 & -1.07 & -0.67 & -0.63 & -0.80 & -0.96 & -0.74 & -1.29 \\
\hline Laos & -0.83 & -0.78 & -1.05 & -1.07 & -0.96 & -0.94 & -0.21 & -0.23 & -1.08 & -0.90 \\
\hline \begin{tabular}{|l} 
Malaysia \\
\end{tabular} & 0.53 & 0.47 & 0.21 & 0.12 & 0.99 & 1.10 & 0.42 & 0.14 & 0.50 & 0.51 \\
\hline Mongolia & 0.27 & -0.31 & -0.02 & -0.71 & -0.20 & -0.61 & 1.08 & 0.51 & 0.20 & -0.43 \\
\hline \begin{tabular}{|l|} 
Oman \\
\end{tabular} & 0.67 & 0.58 & 0.83 & 0.37 & 0.43 & 0.59 & 0.84 & 0.69 & 0.57 & 0.67 \\
\hline \begin{tabular}{|l} 
Nepal \\
\end{tabular} & -0.79 & -1.04 & -0.32 & -0.69 & -0.49 & -0.77 & -1.81 & -1.68 & -0.53 & -1.02 \\
\hline \begin{tabular}{|l|} 
Pakistan \\
\end{tabular} & -0.94 & -1.34 & -0.93 & -1.10 & -0.39 & -0.77 & -1.73 & -2.70 & -0.69 & -0.79 \\
\hline \begin{tabular}{|l|} 
Philippines \\
\end{tabular} & -0.48 & -0.76 & -0.46 & -0.82 & -0.09 & -0.10 & -0.90 & -1.56 & -0.46 & -0.54 \\
\hline Qatar & 0.67 & 1.10 & 0.71 & 1.52 & 0.52 & 0.94 & 0.74 & 1.06 & 0.69 & 0.87 \\
\hline \begin{tabular}{|l} 
Saudi Arabia \\
\end{tabular} & -0.07 & 0.00 & 0.05 & 0.15 & -0.33 & -0.08 & -0.14 & -0.23 & 0.13 & 0.16 \\
\hline \begin{tabular}{|l|} 
Singapore \\
\end{tabular} & 1.70 & 1.81 & 2.35 & 2.18 & 1.84 & 2.25 & 1.16 & 1.12 & 1.45 & 1.69 \\
\hline Vietnam & -0.31 & -0.31 & -0.55 & -0.58 & -0.45 & -0.31 & 0.26 & 0.13 & -0.50 & -0.48 \\
\hline \begin{tabular}{|l|} 
Tajikistan \\
\end{tabular} & -1.14 & -1.05 & -1.04 & -1.17 & -1.26 & -0.91 & -1.05 & -0.91 & -1.21 & -1.20 \\
\hline Thailand & 0.18 & -0.42 & -0.28 & -0.34 & 0.25 & 0.09 & 0.42 & -1.22 & 0.35 & -0.20 \\
\hline \begin{tabular}{|l} 
United Arab Emirates \\
\end{tabular} & 0.90 & 0.74 & 1.23 & 0.98 & 0.84 & 0.78 & 0.78 & 0.82 & 0.76 & 0.39 \\
\hline \begin{tabular}{|l} 
Turkey \\
\end{tabular} & \begin{tabular}{|c|}
-0.41 \\
\end{tabular} & -0.13 & -0.71 & 0.01 & 0.05 & 0.35 & -0.88 & -1.00 & -0.09 & 0.10 \\
\hline \begin{tabular}{|l|} 
Turkmenistan \\
\end{tabular} & -1.01 & -1.06 & -1.18 & -1.44 & -1.53 & -1.58 & -0.04 & 0.24 & -1.29 & -1.46 \\
\hline Uzbekistan & -1.20 & -1.07 & -0.99 & -1.32 & -1.19 & -0.80 & -1.16 & -0.78 & -1.47 & -1.37 \\
\hline Yemen & -1.16 & -1.36 & -0.96 & -1.14 & -0.81 & -1.03 & -1.41 & -2.22 & -1.45 & -1.05 \\
\hline
\end{tabular}

Note: Not all indices on which this study drew provided data for 2002 and 2012; in other cases, data from the closest available year were used. 